\title{
Dan Disney
}

\section{'Does anybody else here not understand?' Language, post-philosophers, bewitchment and confusion: some post-conference reflections}

\author{
Abstract \\ Postmodernism, post-philosophy, in fact any theoretical discourse prefixed with \\ a 'post': what does it all mean? How might creative producers interact with \\ these terms, let alone with the ideas they contain? This essay investigates some \\ recent trends in theoretical thinking, and is a reflection on the author's \\ experience of one particularly complex aesthetics conference.
}

Language speaks, not humans. Humans only speak inasmuch as they respond to language.

(Heidegger 1991: 96)

\section{Introducing 'Sensorium: Aesthetics, Art, Life'}

I attended numerous conferences during my time as a PhD student, and the first left an indelible impression. Sensorium was a conference on 'aesthetics, art, life', co-hosted by a number of departments at the University of Melbourne.[1] Published two years later, if you liked the conference, you'll love the book: a monograph which models a speculative sensorial aesthetics. Rather than 'artists deferring to philosophers in regard to the meaning of their works', the model under proposal seeks to shift power so that philosophers instead 'defer to artists, who are understood as experts and inventers [sic] in the realm of sensibility' (Bolt, Coleman, Jones \& Woodward 2007: xvi). What kind of deference might be entailed? Any yielding or postponing (the etymological roots of 'defer') seems an idealistic goal: after all, isn't art a primary material which, when encountered by aestheticians, is only part of a process in which ideas come to be formulated? What kind of deference - other than lip service - can be possible in this discourse of power relations?

In this paper, rather than mount my own discussion of specific artwork, I critique whether Sensorium meets its paradigm-shifting goals, while reflecting on the (so often problematic) relationship between art and theories of art. 
This thought turned and returned over the three days of Sensorium. What uses might a poet find for philosophies, when the latter can be spoken in such peculiar lexicons? Those presenting at Sensorium were, one way or another, seeking to return 'to the question of life through the subversion of the privileged positioning of the intelligible over the sensible' (Bolt et al 2007: xiii). Indeed. Here was an ambit to upset a hierarchy, to reposition art and artists within a paradigm that had historically privileged theoreticians seeking to make art make sense. What functions would I find for the 'peculiar lexicons' of this conference's writing communities? I felt certain 'the attempt to legitimate art' (Bolt et al 2007: xiii) held great promise for creative producers (like me). How exciting, after all, to attend a conference on aesthetics - that branch of philosophy that 'examines judgments of taste and the feelings of the beautiful and the sublime in relation to nature and art' (Bolt et al 2007: xiii) - that would defer, rather than prescribe, to art makers.

Despite the audacious goal, much of what I experienced during Sensorium was incomprehensible to me. Loudest seemed a version of philosophising that, intent on shifting hegemonies, valorised them instead. Was there something of the legitimising to keynote speaker Arkady Plotnitsky's reminder that philosophers historically regard artists as 'at best, unreliable philosophers'?[2] This was sure to prick the ears of any artist in the audience: what kind of philosophical reliability might Plotnitsky, however unwittingly, have implied? This seems to revisit ancient territory; in The Philosophical Disenfranchisement of Art (1986), contemporary thinker Arthur Danto reviews the Platonic quarrel between poets and philosophers, and identifies 'two disenfranchising moments, aggressions, really' made by philosophies against art:

The first is the effort to ephemeralise art by treating it as fit only for pleasure and the second is the view that art is just philosophy in an alienated form: what it requires, as it were, is only an awakening kiss in order to recognise that it really was philosophy all along, only bewitched. (Danto 1986: xiv-xv)

What might a graduate student researching poetries and poetics do with philosophies that (some philosophers may say) offer wakefulness, when it is only dreams that artists proffer? Had presenters at Sensorium decided that art does the very thing Danto later speculates, that is, 'what philosophy itself does, only uncouthly' (Danto 1986: 7)? Or were these theoreticians doing what art does, but couthly?

A clue is contained in Sensorium: Aesthetics, Art, Life, when the book's editors avow 'the various chapters collected in this volume encompass a variety of styles, from formal academic prose to literary inventiveness'. But this strange proposition then follows:

sensorial affects ... persist in all the chapters here, even the more theoretical. These sensations, which provoke life, persist in all writing about art and aesthetics, because writing itself is an art. (Bolt et al 2007: xix)

There may well have been an attempt made to privilege the sensible over the theoretical responses to art at Sensorium, but what seemed absent from papers delivered at this conference was any kind of deferring. Indeed, in barely discussing art at an aesthetics conference, a gesture was being played out: here were philosophies offered as dominant, legitimising discourses. More so, in using language somewhat like artists, these theoreticians seemed to have done away with the need to discuss art almost at all. 
This was likely to problematise that new relationship Sensorium was seeking to establish (or rekindle): just who exactly was to play the role of artist, and who would act as philosopher deferring - or not - to artists? As Sensorium progressed, it became clear that the papers presented may have been compelling only to a small percentage of gathered cognoscenti. Without exception, each non-presenter I complained to avowed their own state of confusion. Artistic, theoretical complexity as the preferred mode of communication is writ large in the conference handbook: one keynote speaker, for example, delivered an examination of the 'literary-philosophical writing' of Pierre Klossowski, who is described as re-reading the work of Nietzsche and its impact on Deleuze's thinking on art (Sensorium conference guide 2007: 6). This commentary seems to be a style of aesthetics done at three removes from its subject - that is, art viewed through the filter of three different theories, a re-re-re-reflection if you like - and this complex style of analysis typifies the communication strategies of those presenters participating in Sensorium. Were these paraliteratures a kind of art or, I couldn't help but wonder, were they a bewitching style of sophistry?

I have no argument with complexity, though I left Sensorium wondering what had been communicated during this three-day talkfest about 'Art', in which artworks were a mere footnote for theoretical thinking. Far from the Mallarméan poetic gesture (where poets purify the language of the tribe), presenters at this conference seemed to affirm a particular problem. In attempting to articulate their versions of philosophy to non-philosophers, many of whom arrived without foreknowledge of the sub-genre 'aesthetics' (and yet felt themselves to be stakeholders), here were whole days of discourse falling on confused ears. At the end of Sensorium, I was not alone in querying the possible function of presentations that failed to communicate much else beyond multi-syllabic noise. This was 'Art' for aestheticians, not artists; nor even a general academic audience. I began to wonder this: is a particular kind of great reader / listener required to have great aestheticians?

Perhaps so, and this then begs a range of further questions: who is aesthetics for? What does aesthetics do? The term 'aesthetic' gained widespread acceptance in Europe in the mid-eighteenth century, after the publication of Alexander Gottlieb Baumgarten's Reflections on Poetry. Baumgarten writes:

things known are to be known by the superior faculty as the object of logic; things perceived (are to be known by the inferior faculty as the object) of the science of perception, or aesthetic. (Baumgarten 1954 [1735]: 78)

Perhaps a science of perception - categorising? totalising? - is required when truthfulness or knowledge in art becomes so embedded or encoded, so confounding and specialised, that audiences must have it mediated. Will aestheticians, then, humanise art? This was not my experience at Sensorium; instead, in struggling for the naming rights ('truth', 'knowledge'), presenters at Sensorium undertook to theorise on what and how and when 'Art' might be without either practice-led approaches, or much analysis of artworks. Instead, artistic theorisations seem to have become enclosed, self-referential discourses.

In his article, 'We must nurture the humanities', contemporary philosopher Peter Singer asks 'what is excellence in a university?' In surveying the Australian context, he has this to say:

Australian academics in the humanities need to accept a share of the responsibility for the state of their field. In some fields, it has become fashionable to write and talk in a way that few can 
understand. Jargon lends an aura of expertise, but obscures the important issues that are at stake. ( $\underline{\text { Singer 2009) }}$

My polemic here, a challenge really, remains sceptical of the languages of conferences like Sensorium. To agree with Peter Singer's contention: as much as I am interested in ideas and in talking about ideas, I remain frustrated that complexity has been mistaken (or swapped) for excellence. To this poet, working with language differently to those engaged in analytical industries, Sensorium turned into a run of days fraught with disenchantments. Where to from here?

\section{Post-philosophy: a selective history}

In the mid-twentieth century the philosopher of language, Ludwig Wittgenstein, sought to claim some sort of logic-based reliability for the languages of philosophy. In Philosophical Investigations, he writes that 'philosophy is a battle against the bewitchment of our intelligence by means of our language' (Wittgenstein 2001a [1953]: 40) and, in the same book, that 'philosophical problems arise when language goes on holiday' (Wittgenstein 2001a: 16; emphasis in original). Wittgenstein's warning seems prescient for my concern. Beyond the linguistic turn, have the languages of philosophy gone on holiday? The linguistic turn was promulgated halfway through the twentieth century by an emergent group who came to be known as the 'ordinary-language philosophers' (JL Austin, the later Heidegger, and others), which held that concepts 'central to philosophy - e.g., the concepts of truth and knowledge (are) fixed by linguistic practice' (Audi 2001: 635). This turn of emphasis toward language was later extended by, among others, Jacques Derrida who, with his programmatic deconstructive principles, sought to transgress what had hitherto been taken as hermetic linguistic structures. In radicalising the ordinary-language school's endeavours, Derrida risked destabilising the entire project of analytical philosophy by exposing (what he termed) the lack of a 'metaphysics of presence' (Derrida 1978: 279-80). For Derrida, underlying language there were no abstract concepts like truth or knowledge but, simply, more language. After Derrida's truism, there could be no claim to objective viewpoints through the lens of philosophical languages. Truth and knowledge would be contingent - fixed by linguistic practice - rather than absolute.

In the early twenty-first century, it seems thinkers and writers have arrived at the agonistic ends of Derrida et al's postmodern theoretical avant-garde. This reading and writing style has reframed analytical philosophies, literatures, 'high' and 'popular' texts, as an interconnecting mesh woven by the machines of culture ... and I wonder whether it is here that theoretical meaning-making has gone on holiday? In Consequences of Pragmatism, contemporary philosopher Richard Rorty writes of the hybridising inventiveness at work in postmodernism, which he reinvents as post-philosophy. In attempting to define what sort of writing post-philosophers produce, Rorty suggests:

The modern Western 'culture critic' feels free to comment on anything at all. He is a prefiguration of the all-purpose intellectual of a post-Philosophical culture, the philosopher who has abandoned pretensions to Philosophy. He passes rapidly from Hemingway to Proust to Hitler to Marx to Foucault to Mary Douglas to the present situation in Southeast Asia to Ghandi to Sophocles. He is a namedropper, who uses names such as these to refer to sets of descriptions, symbol-systems, ways of seeing. His specialty is seeing similarities and differences between great big pictures, 
between attempts to see how things hang together. He is a person who tells you how all the ways of making things hang together hang together. (Rorty 1982: xl)

To see the world as post-philosophers do is to move between a range of textualities so as to generate a meta-picture of how pictures of the world are made. These theoretical (and at once artistic, if the editors of Sensorium are to be believed) compositions will be limited only by erudition and a theoretician's creative abilities - a style of poeisis that moves into a specific style of postphilosophical techné - which will yoke together sets of arbitrarily assigned meanings. And herein lies a problem.

Specifically, post-philosophical interpretations manifest in more than simply specialised lexicons. These meta-language-games - critiques of language, in language - are so esoteric they seem impossible to decode. An example: what is to be made of the jargon employed by Arkady Plotnitsky in his essay, "'The shadow of the people to come": Chaos, brain, and thought in Deleuze and Guattari' (Chapter 12 of Sensorium: Aesthetics, Art, Life)? Does this writing contain what Rorty calls a meta-picture? Perhaps part of my confusion is that this 'picture' does something with language differently to poetic images (which aim to transfer on to the blank screens of imaginations: I am thinking of Horace's credo, ut pictura poeisis). What is most disenchanting in Plotnitsky's essay is that, in dissecting what art does differently from philosophy and science, the theoretician glances hardly at all toward artwork. Instead, he uses language to achieve the following effects:

sensations, percepts, and affects exist as the products and generators of planes of composition, enacted by and in the material (monument) of a work of art. This plane will be contrasted, in defining art qua art, with the plane of immanence or consistency, inhabited by concepts, in philosophy, and the plane of reference or coordination, inhabited by functions, in science. Each plane of composition in art is defined 'as an image of a Universe (phenomenon)' - a cosmos or chaosmos (chaos-cosmos) or a constellational assemblage of 'affects and percepts' - appearing in the field of thought, in which the thought of art intersects with the chaos of forms that are born and disappear with an infinite speed. Such an image is, however, not a representation of any real world, 'since no art and no sensation have ever been representational'. One may, of course, experience or even create an artwork as a representation, but as such it is not art on Deleuze and Guattari's definition. Such an image may be that of a Universe as chaos, in any of the three senses here considered, but in particular, chaos as the imcomprehensible, of what Blanchot calls 'the unfigurable Universe'. Even in this case, however, it is still an image of a Universe, although in this case the term 'un-mage' would be more appropriate. (Plotnitsky_2007: 181-82)

And so the essay goes, delivering 28 pages of its own incomprehensible chaos. If this were some kind of gnomic prose poem, I might congratulate its author on the text's pastiche and disjuncture, on the use of nonsequitur and truism, and on what seems a parody of the overwrought styles of postmodernity. But this is no prose poem. While a series of arguments is being developed here, what I am at first dazzled and then stunned by is the language Plotnitsky the postphilosopher employs, a language laden with referents from which edicts on 'Art' arrive, while remaining devoid of reflections on specific artwork. This is hardly the necessary technical language of a specialised, theoretical field. What I object to is that the paraliterary inventiveness of jargon like Plotnitsky's has 
become an end in itself, a style that endlessly elaborates while - however unwittingly - obfuscating clarity.

When post-philosophical texts employ this style of language, dialogue becomes all but impossible. The overarching impulse seems to drive toward being as inventive as the aesthetic avant-garde once was. My sense is that texts like Plotnitsky's obscure important issues and, in so doing, subvert a founding principle of philosophy: dialogue is hijacked, and the 'dialectical' arguments and conversations of interested parties (from the Greek dialegein) are arrested. Among some, there is suspicion that this late twentieth-century writing style is a gimmick or, worse, gobbledegook, and that there is nothing (at least nothing of lasting worth) underneath. Contemporary philosopher John Searle perceives postmodernism as a linguistic miasma that, when scrutinised, 'just dissolves like so much mist on a hot day' (Searle 1994: 662). After the postmodern program, in other words, readers may be reminded that philosophies are discursive rather than hermetic. But otherwise, Searle (and many with him) doubts these programmatic texts will serve a long-term purpose. Where to from here, postphilosophers?

\section{Where to from here, post-philosophers?}

In one of post-philosophy's arche-texts, 'Answering the Question: What is Postmodernism?', Jean-François Lyotard calls for a 'war on totality' and suggests that this is a war that can be fought through a unified push from artists and theoreticians alike, away from the aesthetico-theoretical gesture of absolutism and toward a multiplicity of relative ideas. Setting up distance between his program and the universalist principles of the modernists, Lyotard advises his audience of thinkers and writers to 'be witnesses to the unpresentable' (Lyotard 1984: 82). He calls for a writing style that will function 'without rules in order to formulate the rules of what will have been done' (Lyotard 1984: 81). We might imagine the hoisted placards: No Rules! ... except those uniquely established by the work; and it is this antagonistic selfreflexivity by which postmodernism was to arrive. Of course, Lyotard's stricture carries its own (paradoxical) universalist gesture; after all, what but a universal gesture can counteract the antecedent universal gestures of the modernists?

This was no dialectical manoeuvre. Lyotard's was a hostile take-over bid. Challenging nothing less than canonically-set boundaries of ontologicolinguistic reality, Lyotard's speculative model placed trust in a program that emphasized contingency, transgression, and anti-absolutism. But Lyotard set out to establish a revolutionary program that was broader yet: he would promote a mindset that adopted an 'incredulity towards meta-narratives' (Lyotard 1984: xxvi). Aimed toward the incessant 'invention of new rules' (Lyotard 1984: 80), those canonical meta-narratives of truth and knowledge which had been reified since Enlightenment were to be de-limited, abandoned because these same marked the limits of consumer-based, capitalist culture. Commentator Suzanne Guerlac typifies the postmodern program when she writes of how 'theory became our encounter, if not with transcendence, then at least with the limit, the limit between limitation and illimitation' (Guerlac 1991: 902). While I argue that post-philosophical theorisations both test and broach the limits of comprehension, I acknowledge an ethics underpins the proposed transgressions of these first-wave proto post-philosophers. As a mode of revolt, theirs was a program seeking to change the rules of how to formulate speculative knowledge, blending theoria with poeisis in the hope of waging a war on totality in which culture had been commodified. This would begin by unfixing language, so that the grand narratives of truth and knowledge could be 
reapproached; post-philosophies shifted into artistic acts, in which theorising became 'an art'. But, like other avant-garde programs, postmodernism seems to have fallen short of its goals, and is now - and conferences like Sensorium confirm it - little more than a writing style. Just as Auden once proclaimed 'poetry makes nothing happen' (Auden 1977: 242),[]] and just as Heidegger assures his readers that philosophy is 'immediately useless' (Heidegger 1994: 5), the revolutions promised by postmodernists have succumbed to the realities of late-capitalist banality. Where to from here, post-philosophers?

\section{Where to from here, post-philosophers? (ii)}

Allow me, if only for a moment, to attempt a writing experiment. I wish to adopt a writing style that is part theoretical language, part artistic invention, and wholly post-philosophical.

Let's speculate on the future by first glancing backward. In 1882, when Nietzsche declared 'Gott ist tot', the deicide signalled an early marshalling of modern selves toward Postmodern personae: once the godhead was tried in absentia (where else?) and declared dead (Nietzsche 1974: 168), an earlier question, 'what is a human being?' (asked by Kant a century earlier, Kant 1996: $\underline{\mathrm{A} 805}, \underline{\mathrm{B} 833}$ ) was thrown into a whole new light. In wresting control of language, Nietzsche inscribed 'god' as a fallacious and limiting myth; now the word was no longer 'god', and Nietzsche's performative killing was an ultimate transgressive act. But rather than enshrine human agency, the Nietzschean gesture became a model which has since devolved into a lengthening tradition of thanatogenics, a nihilistic death-for-all trope employed over the course of postmodernism. [4] What is this gesture, this endless search for a limit? In an attempt to overcome canonical meta-narratives, it seems postmodernists have replaced these with their own: what remains is a single meta-narrative, Lyotard's contradictory yet totalising command that there shall now be no more meta-narratives. After the death of 'god' there shall be postmodernity; and after? Or have the postmodernists enshrined their own version of the fiat lux?

Let us abandon the fantasies of our philosopher forefathers. After postmodernism, there shall be post-philosophies, where anything - other than absolute truth or knowledge - might be possible. The limit imposed first by a godhead and next by philosophers has been replaced by a simulacrum where what are now imposed, as theoretician Thomas Docherty frames it, 'are only appearances and disappearances, and no claims can be made upon any ontological reality at all' (Docherty 1996: 257). According to another famed voice from postmodernity, Jean Baudrillard, the milieu of the simulacrum is 'no longer that of a territory, a referential being or a substance. It is the generation by models of a real without origin or reality: a hyperreal' (Baudrillard 1983: 2). De-limited, self-deterministic, non-Utopian, post-philosophers define and dictate the parameters of human realities, acting as custodians who maintain the upkeep of an ontological headquarters in which 'representations precede, indeed create, that which they represent' (Hawthorn 2000: 325).

Hasn't this generation of realities been happening since Plato's performative enshrining of an ideal city-state in The Republic? What sort of genre world do post-philosophers model, if grand narratives are abandoned? Baudrillard's simulacrum is a swarming vortex where what is enshrined as hyperreal is a space where artistic theorisations can flow endlessly, an infinite regress of ideas that are limelit momentarily before disappearing into a mass-consumed history of passing curiosities. These ideas are destined to be forgotten, and then forgotten that they have been forgotten. In the aftermath of postmodernism, 
thinkers and writers now confront realities in which canonical discourses of truth and knowledge are rendered not just void but absurd, redundant. Nietzsche once idealised a primal oneness, in which dreams were taken to be 'the illusion of illusion' (Nietzsche 1993: 25). For Lyotard, Baudrillard and their ensuing armies of post-philosopher epigones, all limitation is forsaken, after Nietzsche, for a universe without truth or knowledge. And now? Now we have conferences such as Sensorium, which host presenters who are complicit in echoing a jargon of bewitching language. The illusion of illusions has itself become illusory; the wakefulness of the post-philosophical program portends the maddening industries of insomnia.

\section{Where to from here, post-philosophers? (iii)}

Did my experiment - a rant, to be sure - do what post-philosophies do? Was it a cogent, organically unified invention? And is this a style for creative thinkers and writers to adopt? Not necessarily: for, to take up (and turn) Wittgenstein's aphorism on the role of philosophy, post-philosophies seem to encode a battle against the intelligence of language by means of bewitchment. One recent thinker, Gilles Deleuze, provides a plausible set of characteristics for the postphilosophical enterprise. In What is Philosophy?, he writes:

some concepts must be indicated by an extraordinary and sometimes even barbarous or shocking word, whereas others make do with an ordinary, everyday word that is filled with harmonics so distant that it risks being imperceptible to a nonphilosophical ear. Some concepts call for archaisms, and others for neologisms, shot through with almost crazy etymological exercises. (Deleuze \& Guattari 1994: 7-8)

What uses might a poet find for post-philosophies, when post-philosophers rely on (what ultimately remain ill-defined) 'imperceptibilities' to communicate? Or perhaps I miss the point? What Deleuze seems to be getting at is that a new set of rules -- morphological, tropological, syntactical -- must be learned before individuals can communicate with post-philosophers. This is not particularly new or novel: codes are commonly required when seeking to enter specific genre worlds, and have been since (and probably before) the inscription was first carved on the Temple of Isis (Mother Nature): 'I am all that is, and that was, and that shall ever be, and no mortal hath raised the veil from my face' (Kant 1987: 178-79). Do poems, as Romantic poet Percy Bysshe Shelley speculates in his Defence of Poetry, lift 'the veil from the hidden beauty of the world' (Shelley_1965: 39-40)? Can post-philosophies do the same? Perhaps, though the papers I saw delivered at Sensorium did not seem to set clarity (the unveiling of ideas?) as a goal. As the now notorious Sokal hoax exemplifies,[5] perhaps even those equipped with what Deleuze professes to be a philosophical ear (what is this?) sometimes only pretend to understand these bewitching writing styles. Perhaps creative producers are right to remain sceptical? If philosophy, as Stanley Rosen writes, 'is, and always has been the comprehensive articulation of problematicity' (Rosen 1988: xi), then postphilosophies rupture the historical discourses of analytical philosophy to a point where articulation itself is comprehensively problematised.

When an aesthetics conference such as Sensorium is conducted in tropes where language is taken on holiday, meaning-formation around art and around what artists do stands to be hijacked. As Wittgenstein emphasizes (at least as much as we might assume his italics confer emphasis), 'the limits of my language mean the limits of my world' (Wittgenstein 2001b: 68). While Wittgenstein's is not 
the last word - he has a tendency to use the rhetoric of certainty and truth - what became increasingly clear during Sensorium was a genre world spilling with epigones who all spoke a learned jargon that was not only imperceptible (the derivation is from 'perceive': per- 'entirely' + capere 'take'), but which imposed strictures of incomprehensibility on the genre world of art ... something with which, surely, no artist will be entirely taken. Without decoding, Sensorium's post-philosophies seemed as useful as an unknown foreign language to those thinking and writing in other genre worlds. Where to from here, poets?

\section{What uses might a poet find for philosophies? (ii)}

I wonder at the father of philosophy, Thales, who fell into a well when looking into the night skies reflected below him. Is this fall - I extend it to impute the fall of the analytical philosophical tradition - recalled by the arrival of postphilosophies such as those exhibited at Sensorium? Much like the stars Thales saw reflected on the sheen of the water's surface, ideas can become lucid and clear on the surfaces of language. But there remains a sensate world of objects: if, as Terry Eagleton pragmatically frames it in his recent book, How to Read a Poem, 'language is not what shuts us off from reality, but what yields us the deepest access to it' (Eagleton 2007: 69), then it is clear that analytical philosophy employs its own styles of language in reflecting realities. But when post-philosophers re-read philosophy as purely mimetic, and as a genre that literarily and literally relates stories, then philosophies founder. The figurative water stared into by Thales millennia ago has been refigured, stirred so that the ability to philosophically reflect with language now swirls, convoluted.

Straining to capture a look at the stars (at ideas disappearing as the meniscus of philosophical language breaks) philosophy seems to have fallen, just as its ancient father fell. The traditions and histories of philosophy ripple and disappear, while post-philosophies expend much effort in the perhaps dubious revelation that, underneath these, there is only a void of shifting language.

Perhaps, as ordinary-language philosopher JL Austin frames it in his essay 'Performative Utterances', what is exposed by texts such as those contained in Sensorium: Aesthetics, Art, Life is a particular style, a 'force' (as Austin italicizes it) where what is intended is 'not to report facts but to influence people in this way or that, or to let off steam in this way or that' (Austin 1979: 221). Perhaps this is all I am doing here. But I maintain any over-riding forcefulness such as complexity in the place of clarity, and transgression as compulsive gesture - problematises the possibility of dialogue. When theorising Derridean deconstruction, in Consequences of Pragmatism: Essays 1972-1980, Richard Rorty informs his readers that deconstruction is a style of writing that 'always leads to more writing, and more, and still more' (Rorty 1982: 94). Plotnitsky avers as much, in his obituary to Derrida, 'The Différance of the World: Homage to Jacques Derrida', when he writes 'deconstructive work never ends, as it builds new technologies, new forms of writing' (Plotnitsky_2004: 4). It seems that post-philosophers are not planning a quiet departure (or any departure at all), and their hybridised, paraliterary hegemony seems enshrined. But to this poet, post-philosophical languages remain unconvincing, a style that has become a self-referential, somewhat artless argumentative force.

As a researcher who is primarily a creative producer, the post-philosophical fields seem fraught with disenchantments. The shock that postmodern theory once aimed to administer has overloaded the dialectic of philosophical discourses and, as new theoreticians emerge to stand on the shoulders of theoreticians before them, deconstruction verges on bewitchment. But postphilosophies can also be regarded strategically, as fields populated with ideas 
for creative producers to wander and wonder with. It is here that poems can begin to generate. Through assimilating aphorisms and the 'truth-effects' of post-philosophers, through ekphrastically appropriating whatever language or idea causes me to re-read or makes my mind swarm, I am moving toward an intertextual, critical style of poetry. This reversal of the ficto-critical gesture (a question, I think, of emphasis) privileges the creative use of language and, in particular, poetry (that mediation of meter, sound patterning, and the Aristotlean tropes, which is the business of any poet), while at the same time interacting with post-philosophies creatively. Are artistically theoretical texts 'immediately useless'? For this poet, they are not. But, in finding a use for post-philosophies, I remain sceptical.

I leave the final word to commentators Richard Freadman and Seamus Miller, who frame postmodernism as a form of 'constructivist anti-humanism'. In ReThinking Theory they write:

the 'theory' paradigm comprises three constitutive elements ... One, a repudiation of substantial conceptions of the human subject, be it of authors or of social beings in general; two, a denial of the referential power of language and of literary texts; and three, a repudiation of substantive discourses of value, both moral and aesthetic. (Freadman \& Milller 1985: 4)

First-wave postmodernists were once responsible for freeing thinkers and writers into new interpretative spaces, where new fusions of meaning could arrive through a process of decentring and de-limiting language. But, several generations into a waning theoretical avant-garde, has the impulse to relativise arrived at a point of meaninglessness? A challenge remains: where to from here, post-philosophers?

\section{Notes}

1. Sensorium: Aesthetics, Art, Life was held at the University of Melbourne in June 2005, and was co-hosted by (the now-defunct) School of Creative Arts, in conjunction with the Department of Cinema Studies (housed in the School of Art History, Cinema, Classics and Archaeology) and the Melbourne School of Continental Philosophy (housed by the Department of Philosophy). return to $\underline{\text { text }}$

2. Panel Session: Philosophy and Aesthetics Tuesday 21 June 2005, 6.30pm. The monograph takes up Plotnitsky's point: 'the artist has often been construed as an "unreliable philosopher" - one who thinks in muddled concepts, expressed in a derivative and poor way through sensations, which then need to be "reappropriated" into representations which are in turn clarified in concepts by philosophers.' See Bolt, Coleman, Jones \& Woodward (eds) 2007 Sensorium: Aesthetics, Art, Life: xiii. return to text

3. Auden completes this with 'it survives / In the valley of its saying where executives / Would never want to tamper'. See WH Auden 'In Memory of WB Yeats' in Edward Mendelson (ed $\underline{\text { ed }} 1977$ The English Auden: Poems, Essays and Dramatic Writings 1927-1939: 242. return to text

4. For an elucidation of these ideas, see my 2005 article 'Vale Postmodern Thanatogenics? Towards an Aesthetic Proto-avant-garde' in Traffic 7: 113-29. return to text

5. In the late 1990s, the distinguished journal Social Text published Alan Sokal's article 'Transgressing the Boundaries: Toward a Transformative Hermeneutics of Quantum Gravity' (1996). This article promised to expose profound new truths:

in quantum gravity, as we shall see, the space-time manifold ceases to exist as an objective physical reality; geometry becomes relational and contextual; and the foundational conceptual categories of prior science - among them, existence itself - 
become problematised and relativised. This conceptual revolution, I will argue, has profound implications for the content of a future postmodern and liberatory science. (Sokal \& Bricmont 1998: 200)

See Alan Sokal and Jean Bricmont 1998 Intellectual Impostures, page 200. First published in Social Text 26/27 (Spring/Summer, 1996), pages 217-52, not only did this article fail to deliver its promises: it was a fake. A pastiche of physics and poststructuralism the document was, by the author's admission, 'brimming with absurdities and blatant non sequiturs' (1998: 1). return to text

\section{List of works cited}

Audi, R (ed) 2001 The Cambridge dictionary of philosophy (2nd ed) Cambridge: Cambridge University Press return to text

Austin, JL 1979 Philosophical papers (3rd ed), Oxford \& New York: Oxford University Press return to text

Baudrillard, J 1983 Simulations (trans P Foss, P Patton \& P Beitchman), New York: Semiotext(e) $\underline{\text { return to text }}$

Baumgarten, AG 1954 [1735] Reflections on poetry (trans K Aschenbrenner and WB Holther), Berkeley \& Los Angeles: University of California Press return to text

Bolt, B, F Coleman F, G Jones \& A Woodward (eds) 2007 Sensorium: aesthetics, art, life Newcastle, UK: Cambridge Scholars Publishing return to text

Danto, AC 1986 The philosophical disenfranchisement of art, New York: Columbia University Press return to text

Deleuze, G and F Guattari 1994 What is philosophy? (trans H Tomlinson \& G Burchell), New York: Columbia University Press return to text

Derrida, J 1978 Writing and difference (trans A Bass), Chicago: University of Chicago Press return to text

Docherty, T 1996 After theory, Edinburgh: Edinburgh University Press return to text

Eagleton, T 2007 How to read a poem, Malden, MA, Oxford: Blackwell Publications return to $\underline{\text { text }}$

Freadman, R and S Miller 1985 Re-thinking theory, Cambridge \& New York: Cambridge University Press return to text

Guerlac, S 1991 'The sublime in theory', $M L N$ 106.5, December: 895-909 return to text

Hawthorn, J 2000 A glossary of contemporary literary theory, London: Arnold return to text

Heidegger, M 1991 The principle of reason (trans R Lilly), Bloomington \& Indianapolis: Indiana University Press return to text

Heidegger, M 1994 Basic questions in philosophy: selected 'problems' of 'logic' (trans R Rojcewicz \& A Schuwer), Bloomington \& Indianapolis: Indiana University Press return to text

Kant, I 1996 [1781] Critique of pure reason (trans WS Pluhar), Indianapolis \& Cambridge: Hackett Publishing Company return to text

Kant, I 1987 [1790] Critique of judgment (trans and introduction WS Pluhar), Indianapolis \& Cambridge: Hackett Publishing Company return to text

Leitch, VB (ed) 2001 The Norton anthology of theory and criticism, New York: Norton

Lyotard, JL 1984 The postmodern condition: a report on knowledge (trans G Bennington \& B Massumi), Minneapolis: University of Minnesota Press return to text 
Mendelson, E (ed) 1977 The English Auden: poems, essays and dramatic writings 1927-1939, London: Faber \& Faber return to text

Nietzsche, F 1974 'The joyful wisdom (Book 3) §125 in Oscar Levy (ed), The complete works of Friedrich Nietzsche, New York: Gordon Press return to text

Nietzsche, F 1993 The Birth of Tragedy (trans Shaun Whiteside), London: Penguin Books return to text

Plotnitsky, A 2004 'The différance of the world: homage to Jacques Derrida', Postmodern culture 15.1, September (n.p.) return to text

Plotnitsky, A 2007 '"The shadow of the people to come": chaos, brain, and thought in Deleuze and Guattari', in B Bolt, F Coleman, G Jones \& A Woodward (eds), Sensorium: aesthetics, art, life, Newcastle, UK: Cambridge Scholars Publishing, 181-82 return to text

Rorty, R 1982 Consequences of pragmatism (essays: 1972-1980), Minneapolis: University of Minnesota Press return to text

Rosen, S 1988 The quarrel between philosophy and poetry: studies in ancient thought, New York: Routledge return to text

Searle, JR 1994 'Literary theory and its discontents', New literary history 25.3, 25th Anniversary Issue (Part 1), Summer: 637-67 return to text

Sensorium: Philosophy and Aesthetics 2005, conference guide, Carlton: University of Melbourne, June return to text

Shelley, PB 1965 'A defence of poetry', John E Jordan (ed), The four ages of poetry, New York: The Bobbs-Merrill Company return to text

Singer, P 2009 'We must nurture the humanities', The Age 27 June, at http://www.theage.com.au/national/education/we-must-nurture-the-humanities-20090726dxg1.html return to text

Sokal, A and J Bricmont 1998 Intellectual impostures, London: Profile Books return to text

Wittgenstein, L 2001a [1953] Philosophical investigations (trans GEM Anscombe), Oxford \& Cambridge, Mass.: Blackwell return to text

Wittgenstein, L 2001b [1922] Tractatus Logico-Philosophicus (trans DF Pears and BF McGuiness), London; New York: Routledge return to text

Dan Disney recently completed his doctorate, The Archaic Shudder? Toward a poetics of the sublime, with the University of Melbourne. His critical work is published or forthcoming in Contemporary Aesthetics, New Writing, Traffic, and Consciousness, Literature, and the Arts, and he has poems appearing in forthcoming issues of Meanjin and Blast. He is a managing co-editor of Five Islands Press.

Keywords: art; aesthetics; language

\section{TEXT}

Vol 13 No 2 October 2009

http://www.textjournal.com.au 
Editors: Nigel Krauth \& Jen Webb

Text@griffith.edu.au 